\title{
Safety and Health Issues at Sefula Secondary School of Western Zambia
}

\author{
Kaiko Mubita ${ }^{1}$, Charles M. Namafe ${ }^{2}$ \\ The University of Zambia, School of Education, \\ Department of Language and Social Sciences Education, Lusaka, Zambia
}

\begin{abstract}
Academic attainment is regarded as a decisive factor that determines educational quality. United Nations Children's Fund (UNICEF, 2009) argues that in pursuing such academic attainment, children have the right to learn in a safe and healthy environment and, thus, governments have a clear obligation to provide such environments through appropriate frameworks, guidance and legislation. With reference to the argument by UNICEF, this paper explored safety and health issues at Sefula secondary school of western Zambia. This is partly because this school had been reported in the Zambian media to have had poor safety and health conditions. The study endeavoured to find out the safety and health practices as well as challenges at this school. Using data from focus group discussion and interviews of sixty school stakeholders, this paper established that the school faced challenges in management of safety and health. The main finding from this case study indicated that as much as the school had put in place safety and health measures, there were still outstanding safety and health concerns.
\end{abstract}

Keywords: Safety, Health, School Safety, School Health

\section{INTRODUCTION}

The issue of safety and health in schools and the child's right to receive education, the world over, has been under the spotlight for some years. Thro (2006) contends that the opportunity to pursue formal education, particularly quality education, is meaningless unless the learner is able to pursue his or her educational rights in an environment that is both safe and secure. The Independent Project Trust (IPT, 1999) also explains that a secure school environment has a very low risk of physical, emotional and psychological injury to its occupants. IPT (1999) further argues that a safe school is, therefore, a healthy school although, perhaps, the two do not equal to each other.

Zambia's education policy document, Educating Our Future (GRZ, 1996), notes that teaching and learning are affected by the personal health of members of a school community, while school activities and what is learnt can be powerful factors that influence in promoting the health and wellbeing of pupils. The Zambia Environmental Management Act (2011) also records that 'the right to clean, safe and healthy environment shall include the right of access to the various elements of the environment for recreational, educational, health, spiritual, cultural and economic purposes.' This statement highlights the importance of a safe and healthy environment for the betterment of education.

In spite of the foregoing statements on the importance of school safety and health, the state of school environments in Zambia, especially in rural areas, leaves much to be desired. Most of the schools' learning environments are not in good condition. One such school that has poor safety and health conditions is Sefula secondary school in western Zambia. The poor state of safety and health at this school was reported by the Zambia Watchdog on May 11 Sanitation conditions at Sefula Secondary School". An on the spot check at this school by one of the authors of this paper proved that the above media report was true. The school had poor sanitary conditions, water reticulation, dilapidated school buildings and poor play grounds among other safety and health concerns. Moreover, Muvi TV, a local television station in Zambia also reported that "Sefula school grapples with dilapidated infrastructure" (October 17, 2013). Against this background, this study investigated safety and health issues at Sefula secondary school in western Zambia. Sustainable mitigation measures have been suggested to this effect. This paper presents an outline of the said study. 


\section{AIM}

The aim of the study was to assess safety and health practices and challenges at Sefula secondary school and in so doing, to suggest sustainable mitigations measures to address the identified challenges of that school.

\section{RESEARCH QUESTIONS}

The above aim was addressed through the following specific questions:

(a) what are the safety and health practises at Sefula secondary school?

(b) what challenges are faced by stakeholders of Sefula secondary school in managing safety and health?

(c) what sustainable mitigation measures can be proposed to address the challenges of safety and health identified at the school?

\section{CONCEPTUAL AND THEORETICAL FRAMEWORKS}

\subsection{Conceptual Framework}

The study was guided by what was thought to be a logical process of managing safety and health issues in the context of Sefula Secondary School, herein used as a case study. It is argued that for Sefula Secondary school environment to be safe and healthy, it should have a school safety and health policy, be prepared for emergencies, integrate safety and health issues into planning and carry out risk assessments and audits regularly. This practice may translate into for instance, increased pupil morale, enrolment, retention and completion as well as increased staff morale and retention among other likely benefits.

Figure 1 summarises the concept of a safe and health Sefula Secondary School environment in the context of this study.

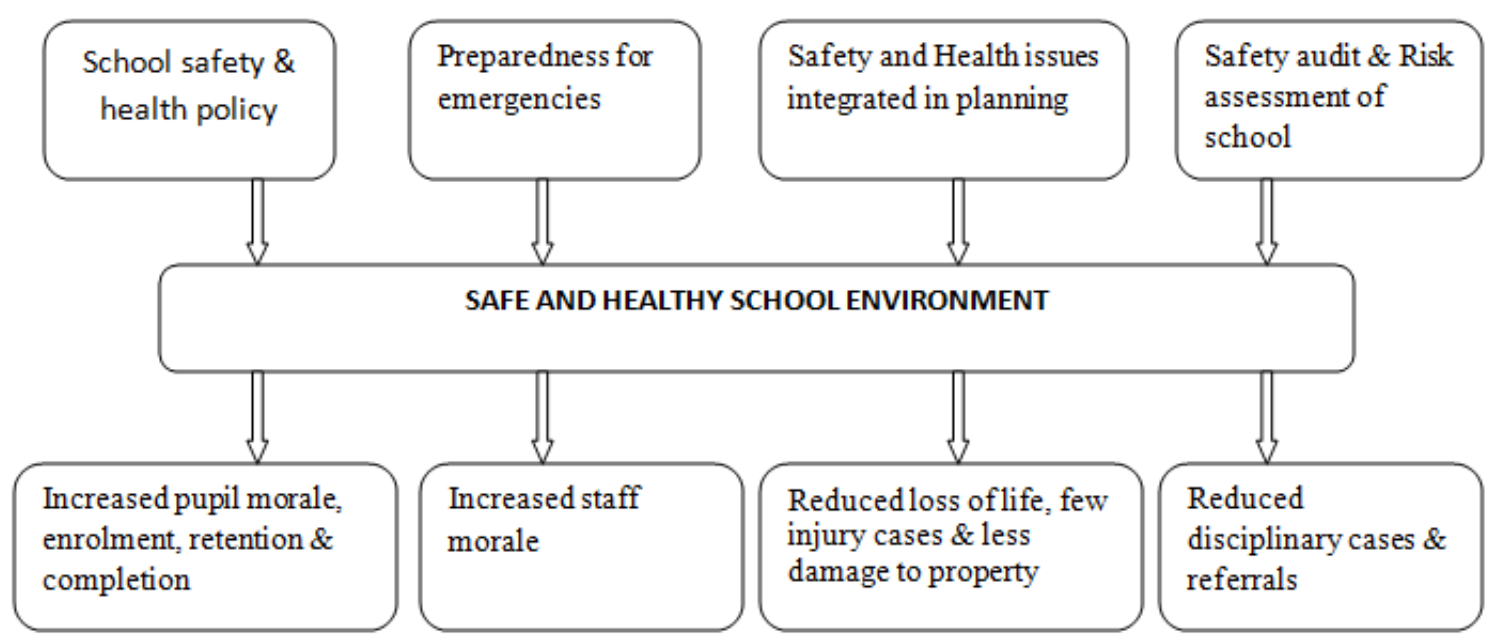

Figure1. Conceptual Frame work for a Safe and Health School

Source: (Field data, 2016)

As presented by figure 1, a safe and health school environment should have safety and health policy, prepared for emergencies, integrate safety and health issues in planning and carry out risk assessments and audits. If all these are done, then, the school is likely to have increased pupil morale, enrolment, retention and completion among other likely benefits.

\subsection{Theoretical Framework}

This study was operationalised through Maslow's Hierarchy of Needs theory. The hierarchy model has basic needs at the bottom and higher needs at the top. These are physiological needs, safety needs, usually categorised as basic needs whereas love needs, esteem needs and self actualisation needs are categorised as secondary or higher needs (Okumbe, 2007). Maslow's theory of motivation states that when a lower need is satisfied, the next highest need becomes dominant and the individuals' attention 
is turned to satisfying this higher need. This theory formed an important base for this study because it identified safety needs as being important to the well-being of people at Sefula Secondary School. After meeting the physiological needs, the stakeholders in the school required assurance that their safety and security needs would be addressed. It was therefore, imperative that Sefula Secondary School management fostered safe and secure environments to facilitate increased learners enrolment, retention, completion and hence attainment of quality education. In short, the adage 'safety first' is appropriately applicable to this school situation. Figure 2 below shows a summary of Maslow's Hierarchy of Needs model.

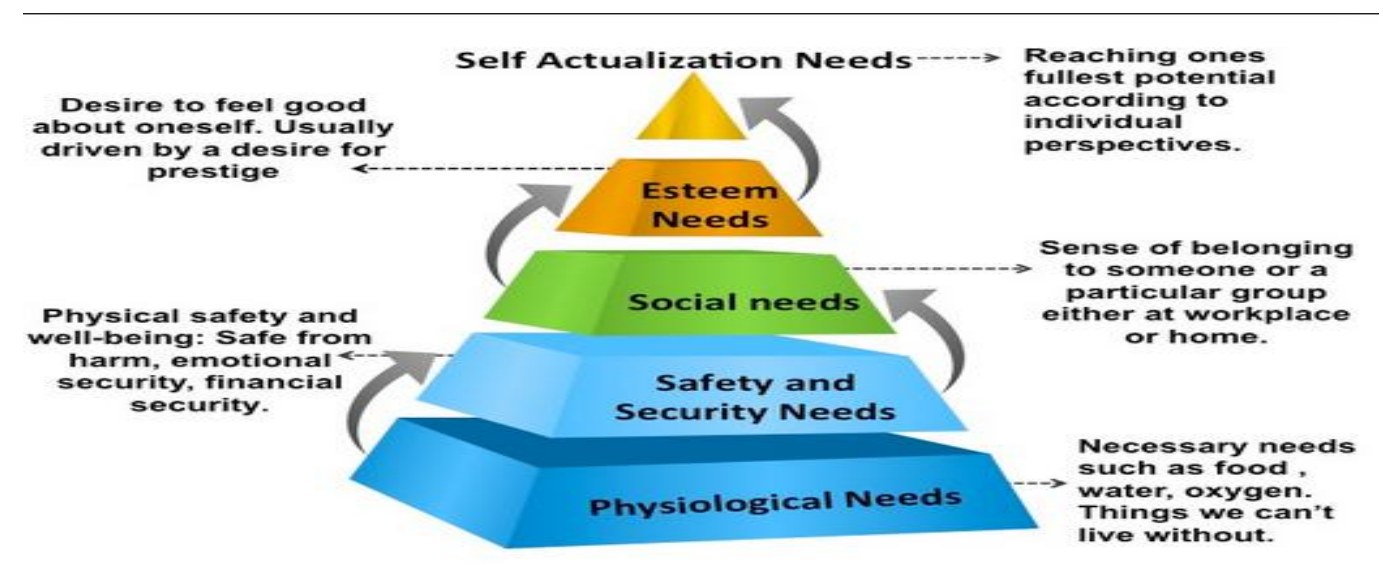

Figure2. Maslow's Hierarchy of Needs model

Source: (Goodman, 1968)

\section{AN OVERVIEW OF LITERATURE}

Nthenya (2011) carried out a study on the participation of secondary school administrators in school safety. Categorically, the study surveyed the implementation of safety policies regarding physical infrastructure and waste management in public schools in Kenya. The study established that there was no deliberate induction targeting school administrators on school safety. Moreover, the study found out that schools did not sort out waste according to type and majority utilised environmentally unsustainable methods of waste disposal. The study found out that there were challenges facing implementation of safety policies such as lack of finances to improve safety policies, unawareness of policy requirements, safety being beyond one's job, and safety not considered as a priority.

In a study conducted by Odalo (2001) it was noted that the absence of firefighting equipment and emergency exits led to the high death toll during the Kyanguli Secondary School fire. Oriang (2001) also noted that lack of perimeter fencing was a source of insecurity at Hawinga Girls secondary school. In 1993, armed gangsters stormed Hawinga Girls Secondary School because the school had no perimeter fencing making it easier for the gangsters to access the school and rape pupils. In a research conducted by Gicheru in 1998, he established that overcrowding was one of the factors that contributed to the death of 27 girls in the 1998 Bombolulu Girls dormitory fire.

All the above reviewed literature confirms that different schools were facing safety and health challenges, just like Sefula secondary school. However, in the above reviewed literature, the studies do not seem to suggest sustainable solutions to the challenges of safety and health in schools. This study proposes some sustainable mitigation measures to challenges of safety and health at Sefula secondary school herein used as a case study.

\section{METHODOLOGY AND RESEARCH APPROACH}

This study is located within the research tradition called interpretivism. Interpretivists contend that only through the subjective interpretation and intervention in reality can that reality be fully understood. Within Sefula secondary school environment, in relation to safety, health and security, there are many interpretations of reality and these interpretations are in themselves a part of the knowledge being pursued.

The study utilised a single case study research design that mainly used qualitative research methods. In view of the fact that environmental safety and health issues differ from one social setting to another, and that all schools are different (Alfred Sloan Foundation, 2004 ) this study concentrated on 
Sefula Secondary School as a single case. Unstructured interviews and focus group discussions were used as data collection methods. The sample size was 60 stakeholders of Sefula Secondary School. Thematic data analysis was utilised for this study. Stakeholders that provided information on safety and health issues of Sefula Secondary School were teachers, pupils, auxiliary staff, parents, the District Education Standards Officer (DESO) and the building officer.

\section{RESUlTS AND DisCUSSION}

\subsection{Safety and Health Practises at Sefula Secondary School}

The study used unstructured interviews to explore safety and health practices that the school put in place then. Knowledge of safety and health measures that the school was using helped to identify the gaps to be filled with regards to safety and health at Sefula secondary school. The response rates were as tabulated in the frequency table 1.

Table1. Safety and health practises at Sefula secondary school

\begin{tabular}{|l|l|l|}
\hline Safety and health practice & Frequency & Percentage (\%) \\
\hline Visitors' book & 4 & 6.7 \\
\hline School rules & 8 & 13.3 \\
\hline Preventive maintenance & 14 & 23.3 \\
\hline Identity cards & 4 & 6.7 \\
\hline Watchmen & 6 & 10 \\
\hline Waste management & 10 & 16.7 \\
\hline School uniform & 6 & 10 \\
\hline Roll call & 8 & 13.3 \\
\hline Total & 60 & 100 \\
\hline
\end{tabular}

Source: Field data, 2016

As noted from the table above, preventive maintenance received the highest response of (23.3\%). This meant that the school practised PMS as a way of keeping the environment clean and healthy. This was followed by waste management at $16.7 \%$. The use of visitors' book and identity cards received the lowest response rates $(6.7 \%)$ from the respondents. This could mean that the visitors' book and identity cards were not highly regarded as reliable practices in keeping the school safe and secure. The variations in response rate as indicated on above table could mean that stakeholders had different ways of identifying, valuing or appreciating certain safety and health measures put in place by the school.

The study further used focus group discussions to explore safety and health practises that the school had put in place then. This assisted the study in finding out what the missing safety and health measures were. According to stakeholders, safety and health measures used at Sefula Secondary School were as follows:

(a)Visitor's book: Although lowly regarded as a safety practice (6.7\%), Sefula Secondary School had a visitor's book. This visitor's book was used in keeping records of who visited the school, at what time and reasons for visiting. A visitor's book at Sefula Secondary School helped the administration to know who was on the premises at any given time. It is very important for many health and safety reasons to know who is inside the school environment. This was noted by one respondent as follows:
"A visitors' book is very important in school settings where the safety of pupils and staff is of utmost importance to ensure people are not put in any danger by suspicious people entering the premises. Visitors in school should log in and out so that the school can know who entered the school at a particular time for safety reasons".

The above view was shared by most respondents interviewed although they expressed it in different ways. The Safety and Security Directorate of New South Wales, Department of Education and Training (2002) also recommends the use of school visitor's book to ensure that all people who do not normally come into school sign in following the official signing in procedure.

(b) School rules: One of the safety and health measures put in place by the school was school rules. The respondents interviewed (13.3\%) indicated that Sefula Secondary School had rules and regulations followed by pupils and staff. These school rules lead to staying safe and focused. This is because school rules are a guide to good and acceptable behaviour among pupils and staff at Sefula Secondary School. 
When pupils in school stay focused, they will most likely get a better education. Staying focused is probably not a written rule, but it is definitely a rule that teachers, administration and parents of Sefula Secondary School want their pupils to follow. This view was supported by other stakeholders on focus group though they explained it in a different way. This foregoing is in agreement with Robert (2008) who also notes that school rules are guidelines for actions and for the evaluation of actions in terms of good and bad, or right and wrong and therefore a part of moral or values education in school.

(c) Preventive Maintenance System (PMS): As noted from the high response rate on table one (23.3\%) Sefula Secondary School practiced PMS in trying to keep the school safe and health. At this school, maintenance of the features of the school's physical environment involved repair, replacement and general upkeep of physical features as found in the school's buildings, grounds and safety systems. This PMS is basically in line with the broken window theory which states that a broken window left unrepaired will make a building look abandoned and will quickly attract vandals to break the other windows (Wilcox, Queensberry, Cabrera \& Jones, 2004).

(d) Identity cards for pupils: The respondents (6.7\%) indicated that Sefula Secondary School uses identity cards as a way of identifying their pupils for safety reasons. Identity cards at Sefula help distinguish pupils from non-pupils and intruders. School identification cards for pupils also help them with options. For example, they could use identity cards to check out library books. This was also in agreement with the Education World (2016) who note that several administrators adopted identity badges as part of an effort to upgrade security spurred by school shootings, terrorist attacks and child abductions.

(e) Watchmen: According to school stakeholders, in order to enhance safety and security, the school employed night watchmen to take care or watch over school property and infrastructure mainly during night time. As noted by the stakeholders, watchmen play a vital role in constructing and maintaining a safe and peaceful environment at Sefula Secondary School, especially during night time. One respondent explained the importance of night watchmen as follows:

"In order to are safe and secure night watchmen ensure safety and security of
pupils, staff and school buildings during assigned work hours. The watchmen
conduct night checks and looks for any acts of vandalism. They also check on
persons idling on school campus. They check unlocked doors, windows and so on.
This has helped this school to be a safe place, especially at night."

The above explanation was agreed by other respondents on focus group though they put it in a different way. Other respondents noted that watchmen played a major role in averting unpleasant events in school.

(f) Waste management: In order to stay healthy, the respondents (16.7\%) explained that the school was involved in a number of ways of managing waste. According to stakeholders, the school was managing waste using rubbish pits and litter bins. This was meant to keep the school health and attractive. The school made sure that the accumulated waste was collected and managed in order to keep the aesthetic beauty of the environment. This waste management practice is in correlation with the Invitational Education theory (Purkey \& Novak, 1996) which states that the school should be an inviting place in relation to programmes, processes, people, policies and places. Good waste management in school would definitely make the school inviting and attractive.

(g) School uniform: The school stakeholders explained that Sefula Secondary School used a uniform for pupils. As noted by one of the respondents, "school uniforms promote pupils' loyalty and reduce pupils' tendency to be violent because they are easily identified." This is in correlation with Elisabetta and Imberman (2010) who observed that school uniforms potentially provide direct improvements in safety by making it easy to identify unauthorized visitors to a school, preventing the use of gang colours and insignia and reducing theft since pupils no longer bring expensive clothing items to school.

(h) Roll call for pupils: At Sefula Secondary School, roll call is conducted for pupils at specified times. This was done in classrooms, assemblies and in dormitories. This was meant to find out which pupil is missing and establish reasons for missing. This helped in making sure that each pupil is conscious of time and be found in the right place at right time. This kept pupils safe and secure. One respondent explained the practice of roll call as follows: 
"This school conducts roll call routinely to find out missing pupils. "Roll call is also conducted to raise awareness of the importance of regular school attendance among pupils. Roll call is also conducted to identify pupils at risk of leaving school early".

The above assertion was agreed by other respondents in the focus discussion group although they put it in different ways.

\subsection{Safety and Health Concerns at Sefula Secondary School}

Despite having some safety and health measures at Sefula secondary school as seen above, the school still had concerns in some areas. Therefore, this study sought to investigate safety and health concerns that the school has been facing in spite of safety and health measures put in place. This helped in finding out the exact issues that the school lacked and suggests sustainable mitigation safety and health measures. This is in correlation with Van Jaarsveld (2011) in her study titled, "An Investigation of Safety and Security Measures at Secondary Schools in Tshwane, South Africa". She observed that despite schools having security measures in place, most schools still had security concerns in relation to security guards, fire alarm systems, limited number of access entry points to school grounds, doors secured with security gates, identity cards for pupils, random drug testing at the school for scholars and adult supervision in halls among others concerns. Responses from the unstructured interview from stakeholders at Sefula secondary school on safety and health concerns were as tabulated on table 2.

Table2. Safety and health concerns at Sefula secondary school

\begin{tabular}{|l|l|l|}
\hline Safety and health concerns & Frequency & Percentage (\%) \\
\hline Lack of CCTV cameras & 4 & 6.7 \\
\hline Poor sanitary conditions & 23 & 38.3 \\
\hline No risk assessments & 4 & 6.7 \\
\hline No perimeter fencing & 5 & 8.3 \\
\hline Poor waste management & 10 & 16.7 \\
\hline No fire fighting equipment & 4 & 6.7 \\
\hline No safety and health policy & 2 & 3.3 \\
\hline No safety and health training & 6 & 10 \\
\hline No safety and health committee & 2 & 3.3 \\
\hline Total & 60 & 100 \\
\hline
\end{tabular}

Source: Field data, 2016

As presented on table 2 above, most respondents (38.3\%) bemoaned poor sanitary conditions in the school. The stakeholders (16.7\%) also explained that the school had poor methods of waste management. The poor waste management practices could have led to poor sanitary conditions and could also lead to prevalence of diseases in school environment. Other notable safety and health concerns were as presented on the table. Safety and health concerns at Sefula Secondary School as noted by stakeholders are discussed below:

(a) Lack of Closed Circuit Televisions (CCTV) cameras: School stakeholders (6.7\%) noted that the school lacked Closed Circuit Televisions (CCTV) surveillance system. This lack of CCTV surveillance system could mean that the school did not have surveillance of areas that were not openly watched by pupils, staff or watchmen. These could be areas prone to violence, theft, vandalism and other crimes. One respondent bemoaned the lack of CCTV cameras as follows:

"If CCTV cameras were in place, they could be used for the wide ranging purpose of protecting this school after working hours and during holidays, as well as provide evidence of violence and crimes to be used in court cases if necessary."

Shepherd (2009) also supports the use of CCTV cameras in schools to curb crime and other forms of insecurity. He explains that south London primary and secondary schools installed CCTV cameras in classrooms to root out bad teachers and check up on naughty pupils and intruders.

(b) Poor sanitary conditions: A number of stakeholders (38.3\%) expressed concern on poor sanitary conditions of Sefula Secondary School. This was reported by Zambia watchdog, an online media in 2014. According to stakeholders, the school had no functioning showers and toilets at the dormitories and classes. Pupils on a daily basis answered the call of nature in the nearby bushes which had been contaminated with faecal matter (Zambia Watchdog, 2014). This state of affairs is also supported by 
Baghri and Wilson (2004) who argue that safe water and environmental sanitation services, that is, waste facilities are vital for people's dignity and health and are especially important in ensuring the healthy development of children.

(c) No risk assessments: According to stakeholders (6.7\%), Sefula Secondary School had not been carrying out risk assessments meant to identify hazards, analyse risks and evaluate associated hazards and consequently determine appropriate ways of eliminating or controlling hazards. This was a safety concern because actual hazards inherent in the school environment were not identified, evaluated and controlled. One respondent expressed her concern as follows:

"This school has not been carrying out risk assessments. This lack of risk assessments means that the school cannot properly spot out hazards inherent in the environment. The school should have been conducting risk assessments to identify hazards and suggest mitigation measures."

This is supported by Hunghes and Ferrent (2011) who argue that employers should be carrying out risk assessment of their work premises to identify hazards and find control measures.

(d) Lack of perimeter fencing: Some stakeholders (8.3\%) of Sefula Secondary School bemoaned lack of a fence around the school. The use of fencing to bolster school security often as part of broader safety plans has become a key issue in discussions of school safety. Fencing may be perceived as a critical factor in making Sefula Secondary School a safer place in the sense that it controls entry of people and automobiles in and out of the school. This is supported by the San Diego Country Office of Education (2003) which asserts that fencing provides security for pupils and staff and is a great way to create territoriality.

(e) Poor waste management: One of the safety and health concerns bemoaned by stakeholders $(16.7 \%)$ at Sefula Secondary School was poor waste management. They noted that waste is not well managed as much as they wanted. Stakeholders bemoaned that activities and action required to manage waste in school from its inception to its final disposal was not well done. The collection, transportation, treatment and disposal of waste together with monitoring and regulation within the school were not pleasing all stakeholders.

The above assertion is supported by Sridhar \& Ojediran, (1983) who argues that problems associated with the poor waste in schools management can lead to diseases, breeding of rats and other vectors of public health importance.

(f) Lack of firefighting equipment: Sefula Secondary School lacked firefighting equipment as presented on table $2(6.7 \%)$. Firefighting equipment is used to extinguish fires. These may include hose reels, fire extinguishers and so on. However, Sefula Secondary lacked firefighting equipment. With reference to the foregoing, on respondent bemoaned this lack of fire fight equipment as follows:

"Our school does not have firefighting equipment. This lack of firefighting equipment means that the school is ill equipped in case of fire. The school does not have fire extinguishers, horse reels and other valuable firefighting equipment."

This is in agreement with the Florida Department of Education (FDoE, 1993) who recommend that firefighting equipment should be located in main circulation paths of the school to help quench fires in case of an emergency.

(g) School safety and health policy: Sefula Secondary School stakeholders bemoaned lack of school safety and health policy to help in guiding governance of safety and health issues in school. This is supported by Hughes and Ferrent (2011) who argue that lack of safety policy for a workplace means no proper guidance on safety issues at that workplace.

(h) Safety and health training and orientation: Thorough safety and health management in school requires that stakeholders are also equipped with knowledge about safety and health issues. However, most stakeholders at Sefula Secondary School bemoaned lack of safety and health training and orientation. This lack of training and orientation meant that pupils and staff were ill equipped in safety and health management of their school environment. This was noted by one respondent as follows:

"In this school, staff and pupils are not trained in safety and health issues. This lack of training in safety and health issues means that staff and pupils are ignorant of how to handle certain safety and health issues. 
This is supported Hunghes and Ferrent (2011) who stress the importance of safety training to ensure that personnel understand their responsibility and accountability for a safety and healthful workplace.

(i) No safety and health committee: according to stakeholders, Sefula Secondary School had no safety and health committee. This was noted as a safety and health concern by stakeholders. This is also against the Occupational Health and Safety Act of 2010 of the Republic of Zambia Part III, section 11 which records that a workplace of ten or more persons shall establish a health and safety committee. The school has more than ten employees and should have had a safety and health committee in accordance with the law.

\section{Proposed Sustainable Mitigation Measures to the Challenges of Safety and Health Management at SEFula SECONDARY SCHOOL}

This study suggested that the following measures be taken by the school in order to manage safety and health issues sustainably:

(a) Carry out risk assessments regularly in order to identify safety and health hazards.

(b) Come up with a school safety and health committee that should spear head safety and health programmes.

(c) Train pupils and staff in school safety and health management issues.

(d) Improve on water reticulation and the state of sanitation infrastructure.

(e) A fence around the school should be built to control entry in and out of the school.

(f) Install firefighting equipment to help in the management of fire safety issues.

(g) Draw a safety and health policy for the school.

(h) Improve school-community relations

\section{CONCLUSION}

This study has explored safety and health practices and challenges faced at Sefula secondary school in western Zambia. The school put up measures to manage safety and health by introducing a visitors' book, employing night watchmen, roll call for pupils, use of identity cards for pupils, preventive maintenance, waste management and so on. Despite the foregoing measures to help keep the school safe and health, the school still had the following concerns: Lack of CCTV cameras, poor sanitary conditions, lack of perimeter fencing, lack of firefighting equipment, no safety policy, no safety and health committee and lack of risk assessments and audits among other concerns. These concerns have to be well managed if the school is to be safe and health.

\section{REFERENCES}

Alfred, P. Foundation. (2004). School safety in the 21st century: adapting to new security challenges post-9/11. Report of the conference "Schools: Prudent Preparation for a Catastrophic Terrorism Incident". October 30-31, 2003, The George Washington University, Washington, D.C.

Baghri, S. \& Wilson, T. (2004). Plan's Approach To Water And Environmental Sanitation. Working Paper Series. Surrey, U.K.: Plan Limited.

Elisabeta, G and Imberman, S.A (2010). Dressed for Success? The Effect of School Uniforms on Student Achievement and Behavior. University of Houston, USA

Ewen, B. R. (2003). An Introduction to Theories of Personality. Lawrence Erlbaum Associate Publishers, London

Florida Department of Education, (1993). Safe School Design Guidelines. Florida: The Florida Centre for Community design + Research

Gicheru, C. (1998). These disasters can be averted. Daily Nation, 28 ${ }^{\text {th }}$ March, 1998,pp 2

Goodman, A. (1968) "On the Operationality of the Maslow need hierarchy". British Journal of Industrial Relation. 6 (1) $51-57$.

Hunghes, H and Ferrent, E. (2011). Introduction to Health and Safety at Work. The handbook for the NEBOSH National General Certificate. Rutledge, Taylor and Francis Group, London

Ministry of Education (1996). Educating Our Future. Lusaka, Zambia 
Nthenya, S.D. (2011). Situation analysis of school safety and school administration participation in public secondary schools: Kenya. International Journal of current Research 3 (6) pp.278-283, June 2011.Retrieved March 23, 2014 from www.ncrel.

Odalo, B. (2001, 27thMarch) Students perish on fire. Daily Nation P.1-2

Okumbe, J. A. (2007). Educational Management, Theory and practice. University of Nairobi Press, Kenya

Oriang,' L. (2001). Taking charge of the welfare of our children. Daily Nation, p. 5. Nairobi: Nation Media Group

Purkey, W. W., \& Novak, J. M. (1996). Inviting School Success: A Self-Concept Approach To Teaching, Learning, And Democratic Practice (3rd ed.). Florence, KY: Wadsworth.

Republic of Zambia. (2010). Occupational Health and Safety Act; Part III, Section 11

Robert, T. (2008). School Children's Reasoning about School Rules. Research Papers in Education, v23 n1 p37-52 Taylor \& Francis, Ltd. 325 Chestnut Street Suite 800, Philadelphia,

San Diego County Office of Education. (2003). Crime Prevention through Environmental Design: How Can It Make Your School Safe? http://www.sdcoe.net/cpted/cpted.asp. [Date accessed: $12 / 05 / 2016]$.

Shephered, J. (2009). Hundreds of schools are installing CCTV cameras in classrooms. Who are they watching and why? Are they really there for training purposes? The Guradian Newspaper, Tuesday, $4^{\text {th }}$ August, 2009.

Sridhar, M.K.C., \& Ojediran, O. (1983). The problems and prospects of refuse disposal in Ibadan City, Nigeria. Journal of Environmental Health, 46(6), 28-31. trunking.tmcnet.com/news/2011/ 09/09/5765046.htm\#sthash.dYGgdT3C.dpuf

The Independent Project Trust. (1999). The Experience Review of Intervention and Programmes Dealing with youth violence in urban schools in South Africa. Durban: IPT

Thro, W. (2006). Judicial Enforcement Of Educational Safety And Security: The American Experience. Perspectives in Education, 24:65-72.

Van Jaarsveld, L. (2011). An investigation of safety and security measures at secondary schools in Tshwane, South Africa. Pretoria: UNISA. Unpublished M.Tech. dissertation. pp. 193.

Wilcox, P; Quisenberry, N; Cabrera, DT; Jones, S (2004), "Busy Places and Broken Windows? Toward Defining the Role of Physical Structure and Process in Community Crime Models", Sociological Quarterly 45 (2): 185-207

Zambia Environmental Management Act (2011) Lusaka, Zambia

Zambia Watchdog (May 11 ${ }^{\text {th }}$,2014) Deplorable Sanitation conditions at Sefula Secondary School. Lusaka, Zambia

\section{AUTHORS' BIOGRAPHY}

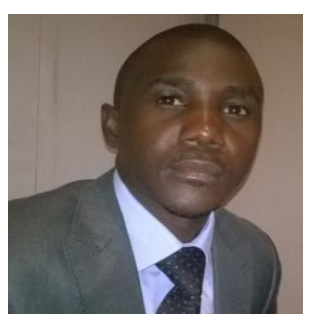

Kaiko Mubita is a lecturer in Geography and Environmental Education at the University of Zambia. He is also a PhD student in Environmental Education at the same institution. His research interests are in occupational health and safety, environmental hazards and disasters and Geography Education.

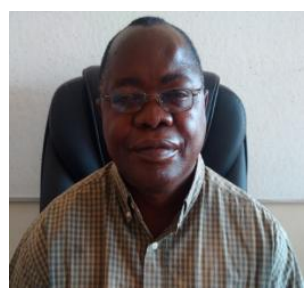

Charles M. Namafe is currently Associate Professor of Environmental Education at the University of Zambia in the School of Education. His research interests are water studies, conflict and its resolution as well as issues to do with culture. 